Pesq. Vet. Bras. 31(6):527-532, junho 2011

\title{
Occurrence of anti-Neospora caninum and anti-Toxoplasma gondii antibodies in dogs with visceral leishmaniasis ${ }^{1}$
}

\author{
Raul R. Ribeiro ${ }^{*}$, Manoel E. Silva ${ }^{3}$, Sydnei M. Silva ${ }^{4}$, Gustavo O. Fulgêncio ${ }^{5}$, Hilda \\ F.J. Pena ${ }^{6}$, Frédéric Frézard ${ }^{7}$, Marilene S.M. Michalick ${ }^{4}$ and Solange M. Gennari ${ }^{6}$
}

\begin{abstract}
Ribeiro R.R., Silva M.E., Silva S.M., Fulgêncio G.O., Pena H.F.J., Frézard F., Michalick M.S.M. \& Gennari S.M. 2011. Occurrence of anti-Neospora caninum and anti-Toxoplasma gondii antibodies in dogs with visceral leishmaniasis. Pesquisa Veterinária Brasileira 31(6):527-532. Centro de Ciências Agrárias Ambientais e Biológicas, Universidade Federal do Recôncavo da Bahia, Campus Universitário Cruz das Almas s/n, Cruz das Almas, BA 44380-000, Brazil. E-mail: raul@ufrb.edu.br

Uninfected dogs and those naturally infected with Leishmania chagasi exhibiting different clinical forms of disease were evaluated for the presence of anti-Neospora caninum and anti-Toxoplasma gondii antibodies. Blood samples were collected from 110 mongrel dogs. Sera were tested using the indirect fluorescent antibody test (IFAT), and the animals with visceral leishmaniasis (VL) $(n=60)$ were classified clinically. Out of the 110 sera investigated, $5(4.5 \%)$ were positive for $N$. caninum (IFAT $\geq 50$ ) and $36(32.7 \%)$ for $T$. gondii (IFAT $\geq 16)$. Anti-L. chagasi antibody titers in asymptomatic dogs $(n=10)$ were found to be significantly lower $(P<0.05)$ than those in oligosymptomatic ones $(n=22)$, which were in turn significantly lower $(P<0.05)$ than those in symptomatic ones $(n=28)$. No association between Leishmania and $N$. caninum infections was observed. Among dogs infected with $L$. chagasi, a tendency $(P=0.053)$ towards an association between the infection with $T$. gondii and the appearance of VL symptoms was observed, suggesting that the clinical manifestation of VL in dogs may enhance their susceptibility to T. gondii. The possible influence of the immunosuppressive status of canine leishmaniasis in the different clinical forms of the disease is discussed.
\end{abstract}

INDEX TERMS: Canine visceral leishmaniasis, Leishmania chagasi, Toxoplasma gondii, Neospora caninum, co-infection, clinical forms.

\footnotetext{
${ }^{1}$ Received on April 27, 2010.

Accepted for publication on November 2, 2010.

2 Centro de Ciências Agrárias Ambientais e Biológicas, Universidade Federal do Recôncavo da Bahia, Campus Universitário Cruz das Almas s/n, Cruz das Almas, BA 44380-000, Brazil. *Corresponding author: raul@ufrb.edu.br

${ }^{3}$ Empresa de Pesquisa Agropecuária de Minas Gerais (Epamig), Rodov. BR MG 352 Km 35, Cx. Postal 43, Zona Rural, Pitangui, MG 35650-000, Brazil.

${ }^{4}$ Departamento de Parasitologia, Instituto de Ciências Biológicas, Universidade Federal de Minas Gerais (UFMG), Av. Antônio Carlos 6627, Belo Horizonte, MG 31270-901, Brazil.

${ }^{5}$ Escola de Veterinária, UFMG, Av. Antônio Carlos 6627, Belo Horizonte, MG 31270-901.

${ }^{6}$ Departamento de Medicina Veterinária Preventiva e Saúde Animal, Faculdade de Medicina Veterinária e Zootecnia, Universidade de São Paulo, Av. Prof. Dr. Orlando Marques de Paiva 87, São Paulo, SP 05508-270, Brazil.

${ }^{7}$ Departamento de Fisiologia e Biofísica, Instituto de Ciências Biológicas, UFMG, Av. Antônio Carlos 6627, Belo Horizonte, MG 31270-901.
}

RESUMO.- [Ocorrência de anticorpos anti-Neospora caninum e anti-Toxoplasma gondii em cães com leishmaniose visceral.] A presença de anticorpos anti-Neospora caninum e anti-Toxoplasma gondii foi avaliada em cães não infectados e naturalmente infectados com Leishmania chagasi manifestando diferentes formas clínicas da enfermidade. Amostras de sangue foram coletadas de 110 cães sem raça definida. Os soros foram avaliados por meio da reação de imunofluorescência indireta (RIFI) e os animais com leishmaniose visceral (LV) $(n=60)$ foram classificados clinicamente. Dos 110 soros analisados, 5 (4,5\%) foram reativos para $N$. caninum $(\mathrm{RIFI} \geq 50)$ e $36(32,7 \%)$ para $T$. gondii (RIFI $\geq 16)$. Os títulos de anticorpos anti- $L$. chagasi em cães assintomáticos $(n=10)$ foram significativamente $(P<0,05)$ mais baixos que aqueles verificados em oligossintomáticos $(n=22)$, que por sua vez foram significativamente menores $(P<0,05)$ que em cães sintomáticos 
( $n=28)$. Não foi observada associação entre infecções por Leishmania e N. caninum. Entre os cães infectados com L. chagasi, verificou-se uma tendência de associação ( $P=0.053$ ) entre infecção com $T$. gondii e aparecimento de sinais clínicos da LV, o que sugere que a manifestação clínica da LV em cães pode aumentar sua susceptibilidade ao $T$. gondii. A provável influência do quadro de imunossupressão em diferentes formas clínicas da leishmaniose canina é abordada.

TERMOS DE INDEXAÇÃO: Leishmaniose visceral canina, Leishmania chagasi, Toxoplasma gondii, Neospora caninum, co-infecção, formas clínicas.

\section{INTRODUCTION}

Leishmaniasis is a group of illnesses transmitted by sand flies that affects domestic and wild animals, as well as humans. Dogs are considered the main reservoir of the etiological agent of visceral leishmaniasis (VL) in the urban context and one of the targets in the control strategy. The clinical characteristics of canine visceral leishmaniasis (CVL) vary from animals that are apparently healthy to animals with severe disease (Blavier et al. 2001), with involvement of multiple organs and a wide variety of cutaneous lesions (Slappendel 1988, Ferrer 1992).

With the emergence of foci of the disease in urban areas, VL has assumed an important role in public health in many regions around the world (Marzochi et al. 1994). In the last several years, the number of human and canine cases of VL in the metropolitan region of Belo Horizonte, Minas Gerais, Brazil, has increased. In addition to the great lethality of disease if left untreated, Leishmania infantum (= L.chagasi), the agent of $V L$, is capable of modulating lymphocyte function, causing severe immunosuppression in the host (Carvalho et al. 1981, Sacks et al. 1987, Pinelli et al. 1994, Reis et al. 2006a). The compromised immune system can facilitate the infection, proliferation and spread of the pathogens after the initial infection and can allow the emergence of latent infection by opportunistic agents. Since the first case of co-infection of human immunodeficiency virus (HIV) and leishmaniasis, studies have demonstrated that this association increases the replication of HIV, as much in vitro as in vivo (Olivier et al. 2003), and consequently accelerates the course of infection by HIV (WHO 1997, Wolday et al. 1999, Cruz et al. 2006).

In VL, as well as in all parasitic diseases, specific factors found in the host and the parasite determines the development of pathogenic lesions and, consequently, the clinical signs of infection (Noli 1999, Handman 2001). Mancianti et al. (1988) evaluated dogs naturally infected with $L$. infantum in Italy and suggested that these animals could be classified as asymptomatic, oligosymptomatic or symptomatic.

Neospora caninum and the related parasite Toxoplasma gondii are cosmopolitan coccidians that cause neurological disease in dogs, using the dog (McAllister et al. 1998) and the cat (Dubey \& Beattie 1988) as the definitive host, respectively; these animals excrete oocysts in their feces, contaminating the environment and infecting a wide range of intermediate hosts.

Co-infection of $L$. infantum and $N$. caninum (Cringoli et al. 1996, Tarantino et al. 2001, Cringoli et al. 2002, Andreotti et al. 2006) and between these parasites and T. gondii (Gennari et al. 2006) has been investigated. Some studies have suggested that the immunosuppression caused by Leishmania sp. could enhance the susceptibility of dogs to N. caninum (Cringoli et al. 2002, Gennari et al. 2006).

The clinical signs of parasitic diseases reflect the interactions of the species or strain with the immune response of the host (Pearson 1993). In VL, the dogs manifest classically distinct clinical forms (Mancianti et al. 1988). The objective of this study was to analyze the humoral immune response against $N$. caninum and $T$. gondii in dogs naturally infected with $L$. chagasi presenting different clinical conditions, and to compare this with healthy dogs' immune response to the same agents.

\section{MATERIALS AND METHODS}

\section{Experimental animals}

The urban dogs used in this study were captured by the Zoonosis Control Center in the county of Santa Luzia, in the metropolitan region of Belo Horizonte, Minas Gerais, Brazil. Sixty dogs of different breeds, of unknown age and naturally infected with $L$. chagasi, were identified during an epidemiological survey of CVL. The infection and serology diagnoses were confirmed by indirect immunofluorescence antibody test (IFAT) and enzymelinked immunosorbent assay (ELISA). In addition, parasitological diagnosis was reached by observations of parasite forms in a cytological examination of bone marrow aspirates. All infected dogs were clinically classified according to Mancianti et al. (1988) as follows: asymptomatic dogs - apparently healthy animals; oligosymptomatic dogs - animals exhibiting lymphoid adenopathy, moderate weight loss and/or dull brittle fur and symptomatic dogs - animals that exhibited the classical signs of the disease such as cutaneous alterations (alopecia, exfoliative dermatitis or ulcers), onicogriphosis, keratoconjunctivitis, cachexia and anemia. Other 50 healthy dogs with negative serological and parasitological diagnosis tests for $L$. chagasi, from the same municipality, also participated of the study as the VL-uninfected control group.

\section{Serological analysis}

Blood samples were obtained by jugular vein puncture utilizing vacutainer-type tubes, and the serum samples were stored at $-20^{\circ} \mathrm{C}$ prior to testing. The diagnosis of VL was conducted through IFAT with a cut-off of 1:40 as described by Camargo (1974) with modifications. The ELISA was carried out according to a technique modified from Voller et al. (1979), using antigen from lysed cultured promastigotes of $L$. chagasi strain MHOM/BR/1967/BH46, and rabbit IgG anti-dog antibody conjugated with horseradish peroxidase. Optical density (OD) readings were done at $490 \mathrm{~nm}$ using a microplate reader (BioRad 2550, Bio-Rad). The serum cut-off corresponded to the average $O D$ of eight samples from $L$. chagasi-negative dogs from a nonendemic leishmaniasis area added to three standard deviations.

Anti- N. caninum and anti-T. gondii antibodies were detected by IFAT based on the studies of Dubey et al. (1988) and 
Camargo (1974), respectively, with cut-off titers of 50 for $N$. caninum and 16 for $T$. gondii. Positive and negative control sera were included in each slide. Positive sera were serially diluted two-fold and tested to establish the maximum reaction titer.

\section{Statistical analysis}

Statistical analyses were conducted using the SPSS software version 9.0 for Windows. Possible associations between samples seropositive and seronegative for Leishmania and the presence of anti- $T$. gondii and anti- $N$. caninum antibodies were analyzed using the Fischer test or the Chi-square test $(P \leq 0.05)$. The comparisons between $T$. gondii and $N$. caninum occurrence in the different VL dog groups were analyzed by Chi-square test $(P \leq 0.05)$.

The comparison of Leishmania titer ranks from asymptomatic, oligosymptomatic and symptomatic dogs was performed using the Kruskal-Wallis test, with the Mann-Whitney test as a post-roc test.

\section{RESULTS}

The antibody titer values and the clinical category of the dogs naturally infected with $L$. chagasiare shown in Table 1. Among the 60 dogs naturally infected with L. chagasi, $10(16.7 \%)$ were clinically classified as asymptomatic, 22 (36.7\%) as oligosymptomatic and $28(46.7 \%)$ as symptomatic. The titers ranged from 80 to 81,920 and the most frequent titer was 20,480 (14/60). There was a significant difference between Leishmania titer ranks among the three clinical forms $(P<0.05)$. Titer ranks from asymptomatic animals were lower than oligosymptomatic titer ranks $(P=0.03)$, which were in turn lower than symptomatic titer ranks $(P=0.03)$.

Table 2 displays the frequency of different clinical signs of $\mathrm{VL}$ in naturally infected dogs (oligosymptomatic and symptomatic). Lymphoadenopathy (44/50, 88\%) was the most frequent sign, followed by skin disorders, which included in decreasing order of frequency, dull fur (40/50, $80 \%)$, exfoliative dermatitis $(38 / 50,76 \%)$, hipotricosis/ alopecia $(30 / 50,60 \%)$ and skin ulcers $(16 / 50,32 \%)$.

Table 1. IgG antibody titers for Leishmania chagasi as evaluated by immunofluorescent antibody test in dogs $(n=60)$ from the municipality of Santa Luzia, Minas Gerais, Brazil

\begin{tabular}{|c|c|c|c|c|c|}
\hline \multicolumn{3}{|c|}{ Leishmania chagasi } & \multicolumn{3}{|c|}{ Clinical forms of Leishmaniasis } \\
\hline \multirow[t]{2}{*}{ Titer } & \multirow{2}{*}{$\begin{array}{c}\text { Number of } \\
\text { positive } \\
\text { dogs }\end{array}$} & \multirow[t]{2}{*}{$\%$} & \multicolumn{3}{|c|}{ Number of dogs } \\
\hline & & & $\begin{array}{l}\text { Asympto- } \\
\text { matic }\end{array}$ & $\begin{array}{l}\text { Oligosympto- } \\
\text { matic }\end{array}$ & $\begin{array}{l}\text { Sympto- } \\
\text { matic }\end{array}$ \\
\hline 40 & 0 & 0 & 0 & 0 & 0 \\
\hline 80 & 1 & 1.7 & 1 & 0 & 0 \\
\hline 160 & 5 & 8.3 & 2 & 3 & 0 \\
\hline 320 & 6 & 10.0 & 2 & 3 & 1 \\
\hline 640 & 3 & 5.0 & 2 & 1 & 0 \\
\hline 1280 & 3 & 5.0 & 1 & 1 & 1 \\
\hline 2560 & 4 & 6.7 & 1 & 2 & 1 \\
\hline 5120 & 3 & 5.0 & 0 & 0 & 3 \\
\hline 10,240 & 7 & 11.7 & 0 & 3 & 4 \\
\hline 20,480 & 14 & 23.3 & 1 & 4 & 9 \\
\hline 40,960 & 10 & 16.7 & 0 & 5 & 5 \\
\hline 81,920 & 4 & 6.7 & 0 & 0 & 4 \\
\hline Total (\%) & 60 & 100 & $10(16.6)$ & $22(36.6)$ & $28(46.6)$ \\
\hline
\end{tabular}

Table 2. Frequency of different clinical signs in dogs $(n=50)$ naturally infected with Leishmania chagasi from Santa Luzia, Minas Gerais, Brazil

\begin{tabular}{lcc}
\hline Clinical signs & $\begin{array}{c}\text { Number } \\
\text { of dogs }\end{array}$ & $\begin{array}{c}\text { Percent with } \\
\text { symptom }\end{array}$ \\
\hline Lymphoadenopathy & 44 & 88 \\
Dull fur & 40 & 80 \\
Exfoliative dermatitis & 38 & 76 \\
Hypotrichosis / Alopecia & 30 & 60 \\
Skin ulcers & 16 & 32 \\
Emaciation & 16 & 32 \\
Nasal hyperkeratosis & 12 & 24 \\
Ophthalmopathies & 12 & 24 \\
Onicogriphosis & 4 & 8
\end{tabular}

Table 3. IgG antibody titers for Neospora caninum and Toxoplasma gondii as evaluated by immunofluorescent antibody test in dogs $(n=110)$ from the municipality of Santa Luzia, Minas Gerais, Brazil

\begin{tabular}{|c|c|c|c|c|c|}
\hline \multicolumn{3}{|c|}{ N. caninum } & \multicolumn{3}{|c|}{ T. gondii } \\
\hline Titer & $\begin{array}{c}\text { Number } \\
\text { of positive } \\
\text { dogs }\end{array}$ & $\begin{array}{c}\text { Occurrence } \\
(\%)\end{array}$ & Titer & $\begin{array}{c}\text { Number } \\
\text { of positive } \\
\text { dogs }\end{array}$ & $\begin{array}{c}\text { Occurrence } \\
(\%)\end{array}$ \\
\hline \multirow[t]{8}{*}{50} & 5 & 100.0 & 16 & 4 & 11.1 \\
\hline & & & 32 & 3 & 8.3 \\
\hline & & & 64 & 5 & 13.9 \\
\hline & & & 128 & 9 & 25.0 \\
\hline & & & 256 & 5 & 13.9 \\
\hline & & & 512 & 3 & 8.3 \\
\hline & & & 1,024 & 5 & 13.9 \\
\hline & & & 4,096 & 2 & 5.6 \\
\hline Total & 5 & 4.5 & & 36 & 32.7 \\
\hline
\end{tabular}

Table 4. Occurrence of antibodies against Neospora caninum and Toxoplasma gondii in dogs positive $(n=60)$ and negative $(n=50)$ for Leishmania chagasi from the municipality of Santa Luzia, Minas Gerais, Brazil

\begin{tabular}{lccc}
\hline & \multicolumn{3}{c}{ L. chagasi } \\
\cline { 2 - 4 } & Positive(\%) & Negative(\%) & $P$ value \\
\hline T. gondii & & & \\
$\quad$ Positive & $15(25.0)$ & $21(42.0)$ & $0.058^{\mathrm{a}}$ \\
$\quad$ Negative & $45(75.0)$ & $29(58.0)$ & \\
N. caninum & & & \\
$\quad$ Positive & $2(3.3)$ & $3(6.0)$ & $0.657^{\mathrm{b}}$ \\
$\quad$ Negative & $58(96.7)$ & $47(94.0)$ & \\
\hline a Chi-square Test. & & & \\
b Fisher Test. & & \\
Ophthalmopathies were observed in 12 of $50(24 \%)$ dogs
\end{tabular}
and onicogriphosis was observed in $8 \%(4 / 50)$ of the animals.

Table 3 illustrates the antibody titer values found for $N$. caninum and T. gondii. The occurrence of anti-N. caninum antibodies was $4.5 \%(1.5 \%<95 \% \mathrm{Cl}<10.3 \%)$ with 5 positive out of 110 dogs, all with titers of 50 . For T. gondii, 36 out of 110 dogs $(32.7 \%)$ had positive results $(24.1 \%<\mathrm{Cl}$ $95 \%<42.3 \%$ ) and titers ranged from 16 to 4,096, with 128 being the most frequent titer (9/36).

Table 4 presents the occurrence of anti- T. gondii and anti$N$. caninum antibodies in dogs positive and negative for $L$. 
Table 5. Occurrence of antibodies against Neospora caninum and Toxoplasma gondii in dogs infected with Leishmania chagasi with different clinical forms of canine leishmaniasis $(n=60)$ and in non-infected control dogs $(n=50)$ from the municipality of Santa Luzia, Minas Gerais, Brazil

\begin{tabular}{lccc}
\hline Clinical Signs & \multirow{N}{*}{$\begin{array}{c}\text { of Dogs } \\
(\%)\end{array}$} & \multicolumn{2}{c}{ № of Positive Dogs(\%) } \\
\cline { 3 - 4 } & N. caninum & T. gondii \\
\hline Asymptomatic & $10(16.7)$ & $0(0.0)^{\mathrm{a}}$ & $0(0.0)^{\mathrm{a}}$ \\
Oligosymptomatic & $22(36.7)$ & $1(4.5)^{\mathrm{a}}$ & $7(31.8)^{\mathrm{a}}$ \\
Symptomatic & $28(46.6)$ & $1(3.6)^{\mathrm{a}}$ & $8(28.6)^{\mathrm{a}}$ \\
Absence & $10(16.7)$ & $0(0.0)^{\mathrm{a}}$ & $0(0.0)^{\mathrm{a}}$ \\
Presence & $50(83.3)$ & $2(2.5)^{\mathrm{a}}$ & $15(30.0)^{\mathrm{b}}$ \\
Total & $60(100.0)$ & $2(3.3)^{\mathrm{c}}$ & $15(25.0)^{\mathrm{d}}$ \\
Control Group & $50(100.0)$ & $3(6.0)^{\mathrm{c}}$ & $21(42.0)^{\mathrm{d}}$ \\
Total & $110(100,0)$ & $5(4,5)$ & $36(32,7)$
\end{tabular}

Comparisons are between categories in the same column.

a $P \geq 0.05$ (Chi-square Test).

b $P=0.053$ (Fisher Test).

c $P=0.657$ (Fisher Test).

d $P=0.058$ (Chi-square Test).

chagasi infection. The occurrence of anti- $N$. caninum antibodies was $6.0 \%(3 / 50)$ in the $L$. chagasi-negative group, whereas in the L. chagasi seropositive group, the occurrence was $3.3 \%(2 / 60)$. No association between Leishmania infection and presence of anti- $N$. caninum antibodies was observed $(P=0.657)$. An occurrence of $42.0 \%(21 / 50)$ and $25.0 \%(15 /$ 60) of anti- T. gondii antibodies in the seronegative and seropositive $L$. chagasi groups, respectively, was observed. The statistical analyses showed no significant association between canine leishmaniasis and T. gondiiantibodies. However, when the presence (oligosymptomatic and symptomatic) or absence (asymptomatic) of clinical signs in VL dogs were evaluated (Table 5), a tendency of association was observed with a $P$ value in the limit of significance ( $P=0.053$, Fisher Test), with higher occurrence of infection of $T$. gondii in animals with symptoms of VL. No significant difference was observed among $T$. gondii titer ranks between the oligosymptomatic and symptomatic groups ( $P>0.05)$.

In the VL-infected group, 3.3\% (2/60) of the animals were simultaneously positive for $N$. caninum and $T$. gondii, and in the Leishmania seronegative group, co-infection was observed in $2.0 \%(1 / 50)$ of the dogs. The proportion test revealed no significant difference in $T$. gondii and $N$. caninum co-infections in the $L$. chagasi positive or negative groups ( $P>0.05)$.

\section{DISCUSSION}

Studies with dogs infected with Leishmania spp. and associations with other coccidian parasites have been conducted; however, different results were observed. Coinfection among these three parasites have been studied in dogs from Brazil by Gennari et al. (2006) in Araçatuba, SP, however, the clinical status of the animals relative to VL was not reported. In the study conducted in Araçatuba, the prevalence of N. caninum (17.6\%) and T. gondii (36.8\%) was higher than the values found in the present study, and an association between the presence of $L$. chagasi and $N$. caninum antibodies was observed.

Two other studies conducted in Mato Grosso do Sul, Brazil (Andreotti et al. 2006) and in South of Italy (Cringoli et al. 2002) observed, respectively, a lack of association and an association between $L$. chagasi and $N$. caninumpositive dogs. Also in Italy, a description of a single case of a simultaneous infection with $L$. infantum and $N$. caninum in a dog with a skin infection was reported. The authors concluded that the immunosuppressive effect of $L$. infantum may have contributed to the development of the N. caninum infection; however, based on histological features, the skin lesions observed were most likely due to Leishmania (Tarantino et al. 2001).

In the present study, $N$. caninum seroprevalence was $4.5 \%$, and its occurrence in Leishmania positive (3.3\%) and negative $(6.0 \%)$ dogs was lower than the values observed in dogs from other regions of Brazil (Gennari et al. 2002, Cañón-Franco et al. 2003, Azevedo et al. 2005, Andreotti et al. 2006, Gennari et al. 2006), indicating a low rate of environmental exposure of the dogs in the region to this agent. Another explanation for the relatively low occurrence of anti- $N$. caninum antibodies is the feeding habits of the dogs in urban areas, where the diet is mainly based on commercial food and contact with other sources of animal products is reduced. Studies have demonstrated significant differences in N. caninum occurrence in rural and urban dogs (Wouda et al. 1999, Fernandes et al. 2004, Wanha et al. 2005), and between stray and owned animals (Gennari et al. 2002), with low values for the owned and urban dogs. The dogs from the present study were captured by the Zoonosis Control Center, so the majority was stray dogs with a higher opportunity to acquire the oocysts contaminating the environment.

All dogs with anti- $N$. caninum antibodies had titers of 50, and against T. gondii, the most frequent titer was 128 . In a cross-section study conducted in apparently healthy dogs from the state of Paraíba, in the northeast region of Brazil, $50 \%$ of the seropositive dogs presented low titers; however, very high titers were also observed for both coccidian parasites (Azevedo et al. 2005).

Toxoplasma gondii occurrence was significantly higher than that of $N$. caninum in tested dogs from both groups, which is expected based on observations from other regions from Brazil (Souza et al. 2002, Souza et al. 2003, Azevedo et al. 2005, Dubey et al. 2007), reflecting the high exposure of this host to $T$. gondii in Brazil and the fact that dogs are considered good sentinels for $T$. gondii environmental contamination (Dubey \& Beattie 1988).

The co-infection between coccidians in the dogs was $2.0 \%(1 / 50)$, and $3.3 \%(2 / 60)$ of animals were simultaneously positive for all three parasites. These data were similar with previous studies, in which co-infection of $N$. caninum and T. gondii in dogs varied between $1 \%$ and $3 \%$ (Lindsay et al. 1990, Mineo et al. 2001), and was different from the $17.3 \%$ observed by Gennari et al. (2006).

The number of dogs positive for N. caninum in each $L$. 
chagasi clinical group was not significantly different, suggesting that $\mathrm{VL}$, independently of the clinical form of disease, does not influence $N$. caninum infection. When $\mathrm{VL}$ dogs were analyzed as a single group, no association between Leishmania infection and the presence of antibodies against $N$. caninum was observed. Similar results were found in asymptomatic dogs from Campo Grande (Andreotti et al. 2006). However, Gennari et al. (2006) verified a significant association between dogs naturally infected with $L$. chagasiand high occurrence of anti- $N$. caninum antibodies (8.6 times greater than VL negative dogs). Cringoli et al. (2002), studying 1,058 asymptomatic dogs from Italy, also reported the same association and suggested that immunosuppression is likely the cause of the greater prevalence of $N$. caninum in Leishmania seropositive dogs.

Toxoplasmosis is a disease usually associated with immunosuppressive disorders (Innes 1997). In the present survey, among dogs infected with L. chagasi, a tendency of association between infection with $T$. gondii and presence of symptoms was verified, suggesting that the clinical form of canine leishmaniasis seems to enhance susceptibility to $T$. gondii. It is expected that the immunodeficiency caused by Leishmania helped underlying agents and subsequently, an immune response to these agents was mounted. In humans, mice (Liew \& O'Donnell 1993) and dogs (Cabral et al. 1992, Pinelli et al. 1994, Pinelli et al. 1995), it was demonstrated that protective immunity against leishmaniasis is mediated by T cells and is associated with the production of IFN- $\gamma$. The ineffectiveness of cellular immunity is a basic aspect of pathogenesis of the illness and its progression (Alvar et al. 2004). Due to the ineffectiveness of cellular immunity in infected dogs, it is likely that dogs with VL that are manifesting symptoms facilitate the multiplication and spread of parasites that are primarily controlled by cellular defenses, such as T. gondii (Denkers \& Gazzinelli 1998), when compared to asymptomatic dogs, in which protective cellular immunity is present (Cabral et al. 1992, Pinelli et al. 1994, Pinelli et al. 1995).

Some authors have shown that detection of antibodies indicates presence of the parasite, but antibodies titers are not correlated with the severity of clinical signs or presentation of the illness in canine VL (Abranches et al. 1991, Ferrer et al. 1995, Campino 2002). However, in this study, significant levels of anti-Leishmania antibodies were observed in different clinical groups, with higher titers in symptomatic dogs. Other publications have also noted a correlation between the levels of immunoglobulin isotypes and different clinical forms of canine VL (Almeida et al. 2005, Reis et al. 2006b, Costa-Val et al. 2007).

The clinical signs seen in the dogs in this experiment corroborated the results of the majority of authors (Slappendel 1988, Ciaramella et al. 1997, Koutinas et al. 2001, Amusategui et al. 2003, Costa-Val et al. 2007), and demonstrated lymphoadenopathy as the most common clinical manifestation of the disease.

Further studies involving different immunological aspects of the infection should be developed with dogs infec- ted with Leishmania, including all clinical forms, to determine the role of the immune system in co-infection by other parasites.

Acknowledgements.- To Mr. Ricardo A. Dias for guidance in statistical analysis, and Mrs. Elza Moreira and Mr. Weverton M. Sampaio for technical support. This research was supported by the Laboratório de Sorologia/ICB/UFMG and the Laboratório de Doenças Parasitárias/ FMVZ/USP.

\section{REFERENCES}

Abranches P., Silva-Pereira M.C.D., Conceição-Silva F.M., SantosGomes G.M. \& Janz J.G. 1991. Canine leishmaniasis: Pathological and ecological factors influencing transmission of infection. J. Parasitol. 77:557-561.

Almeida M.A.O., Jesus E.E.V., Sousa-Atta M.L.B., Alves L.C., Berne M.E.A. \& Atta A.M. 2005. Antileishmanial antibody profile in dogs naturally infected with Leishmania chagasi. Vet. Immunol. Immunopathol. 106:151-158.

Alvar J., Cañavate C., Molina R., Moreno J. \& Nieto J. 2004. Canine leishmaniasis. Adv. Parasitol. 57:1-88.

Amusategui I., Sainz A., Rodriguez F. \& Tesouro M.A. 2003. Distribution and relationships between clinical and biopathological parameters in canine leishmaniasis. Eur. J. Epidemiol. 18:147-156.

Andreotti R., Oliveira J.M., Silva E.A., Oshiro L.M. \& Matos M.F. 2006. Occurrence of Neospora caninum in dogs and its correlation with visceral leishmaniasis in the urban area of Campo Grande, Mato Grosso do Sul, Brazil. Vet. Parasitol. 135:375-379.

Azevedo S.S., Batista C.S., Vasconcellos S.A., Aguiar D.M., Ragozo A.M., Rodrigues A.A., Alves C.J. \& Gennari S.M. 2005. Seroepidemiology of Toxoplasma gondii and Neospora caninum in dogs from the state of Paraíba, Northeast region of Brazil. Res. Vet. Sci. 79:51-56.

Blavier A., Keroack S., Denerolle P.H., Goy-Thollot I., Chabanne L., Cadore J.L. \& Bourdoiseau G. 2001. Atypical forms of canine leishmaniosis. Vet. J. 162:108-120.

Cabral M., Grady J.O. \& Alexander J. 1992. Demonstration of Leishmania specific cell mediated and humoral immunity in asymptomatic dogs. Parasite Immunol. 14:531-539.

Camargo M.E. 1974. Introdução às técnicas de imunofluorência. Revta Bras. Patol. Clín. 10:143-171.

Campino L.M. 2002. Canine reservoirs and leishmaniasis: Epidemiology and disease, p.45-57. In: Farrel J.P. (Ed.), World Class Parasites: Leishmania. Kluwer Academic Publishers, Boston.

Cañón-Franco E.A., Bergamaschi D.P., Labruna M.B., Camargo L.M.A., Souza S.L.P., Silva J.C.R., Pinter A., Dubey J.P. \& Gennari S.M. 2003. Prevalence of antibodies anti-Neospora caninum in dogs from Amazon, Brazil. Vet. Parasitol. 115:71-74.

Carvalho E.M., Teixeira R.S. \& Johnson W.D. 1981. Cell mediated immunity in American visceral leishmaniasis: Reversible immunosuppression during acute infection. Infec. Immun. 22:649-654.

Ciaramella P., Oliva G., De Luna R., Gradoni L., Ambrosio R., Cortese L., Scalone A. \& Persechino A.A. 1997. A retrospective clinical study of canine leishmaniasis in 150 dogs naturally infected by Leishmania infantum. Vet. Rec. 141:539-543.

Costa-Val A.P., Cavalcanti R.R., Gontijo, N.F., Mickalick, M.S.M., Alexander B., Williams P. \& Melo M.N. 2007. Canine visceral leishmaniasis: Relationships between clinical status, humoral imune response, hematology and Lutzomyia (Lutzomyia) longipalpis infectivity. Vet. J. 174:637-643.

Cringoli G., Capuano F., Veneziano V., Romano L., Solimene R., Barber S.J. \& Trees A.J. 1996. Prevalence of antibodies against Neospora caninum in dog sera. Parasitol. 38:283. 
Cringoli G., Rinaldi L., Capuano F., Baldi L., Veneziano V. \& Capelli G. 2002. Serological survey of Neospora caninum and Leishmania infantum co-infection in dogs. Vet. Parasitol. 106:307-313.

Cruz I., Nieto J., Moreno J., Canãvate C., Desjeux P. \& Alvar J. 2006. Leishmania/HIV co-infections in the second decade. Indian J. Med. Res. 123:357-388.

Denkers E.Y. \& Gazzinelli R.T. 1998. Regulation and function of T-cell mediated immunity during Toxoplasma gondii infection. Clin. Microbiol. Rev. 11:569-588.

Dubey J.P. \& Beattie C.P. 1988. Toxoplasmosis of animals and man. CRC Press, Boca Raton, Florida. 220p.

Dubey J.P., Carpenter J.L., Speer C.A., Topper M.J. \& Uggla A. 1988. Newly recognized fatal protozoan disease of dogs. J. Am. Vet. Med. Assoc. 192:1269-1285.

Dubey J.P., Gennari S.M., Sundar N., Vianna M.C., Bandini L.M., Yai L.E., Kwok C.H. \& Suf C. 2007. Diverse and atypical genotypes identified in Toxoplasma gondii from dogs in São Paulo, Brazil. J. Parasitol. 93:60-64.

Fernandes B.C., Gennari S.M., Souza S.L., Carvalho J.M., Oliveira W.G. \& Cury M.C. 2004. Prevalence of anti-Neospora caninum antibodies in dogs from urban, periurban and rural areas of the city of Uberlândia, Minas Gerais-Brazil. Vet. Parasitol. 123:33-40.

Ferrer L. 1992. Leishmaniasis, p.266-270. In: Kirk R.W. \& Bonagura J.D. (Eds), Current Veterinary Therapy Vol.II. W.B. Saunders, Philadelphia.

Ferrer L., Aisa M.J., Roura X. \& Portús M. 1995. Serological diagnosis and treatment of canine leishmaniasis. Vet. Rec. 36:514-516.

Gennari S.M., Yai L.E.O., D’Áuria S.N.R., Cardoso S.M.S., Kwok O.C.H., Jenkins M.C. \& Dubey J.P. 2002. Occurrence of Neospora caninum antibodies in sera from dogs of the city of São Paulo, Brazil. Vet. Parasitol. 106:177-179.

Gennari S.M., Cañon-Franco W.A. \& Feitosa M.M. 2006. Presence of anti-Neospora caninum and Toxoplasma gondii antibodies in dogs with visceral leishmaniosis from the region of Araçatuba, São Paulo, Brazil. Braz. J. Vet. Res. Anim. Sci. 43:613-619.

Handman E. 2001. Leishmaniasis: Current status of vaccine development. Clin. Microbiol. Rev. 14:229-243.

Innes E.A. 1997. Toxoplasmosis: Comparative species susceptibility and host immune response. Comp. Immunol. Microbiol. Infect. Dis. 20:131-138.

Koutinas A.F., Saridomichelakis M.N., Mylonakis M.E., Leontides L., Polizopoulou Z., Billinis C., Argyriadis D., Diakou N. \& Papadopoulos O. 2001. A randomized, blinded, placebo-controlled clinical trial with allopurinol in canine leishmaniosis. Vet. Parasitol. 98:247-261.

Liew F.Y. \& O'Donnell C.A. 1993. Immunology of leishmaniasis. Adv. Parasitol. 32:161-259.

Lindsay D.S., Dubey J.P., Upton S.J. \& Ridley R.K. 1990. Serological prevalence of Neospora caninum and Toxoplasma gondii in dogs from Kansas. J. Helminthol. Soc. Wash. 57:86-88.

Mancianti F., Gramiccia M., Gradoni L. \& Pieri S. 1988. Studies on canine leishmaniais control. I. Evolution of infection of different clinical forms of canine leishmaniasis following antimonial treatment. Trans. R. Soc. Trop. Med. Hyg. 82:566-567.

Marzochi M.C., Marzochi K.B. \& Carvalho R.W. 1994. Visceral leishmaniasis in Rio de Janeiro. Parasitol. Today 10:37-40.

McAllister M.M., Dubey J.P., Lindsay D.S., Jolhey W.R., Wills R.A. \& McGuire A.M. 1998. Dogs are definitive hosts of Neospora caninum. Int. J. Parasitol. 28:1473-1478.

Mineo T.W., Silva D.A., Costa G.H., Von-Ancken A.C., Kasper L.H., Souza M.A., Cabral D.D., Costa A.J. \& Mineo J.R. 2001. Detection of IgG antibodies to Neospora caninum and Toxoplasma gondii in dogs examined in a veterinary hospital from Brazil. Vet. Parasitol. 98:239-245.

Noli C. 1999. Leishmaniasis canina. Waltham Focus 9:16-24.

Olivier M., Badaró R., Medrano F.J. \& Moreno J. 2003. The pathogenesis of Leishmania/HIV co-infection: Cellular and immunological mechanisms. Ann. Trop. Med. Parasitol. 97:79-98.

Pearson R.D. 1993. Pathology of leishmaniasis, p.71-86. In: Warren K.S. (Ed.), Immunology and molecular biology of parasitic infections. $3^{\text {rd }}$ ed. Blackwell Publications, Boston.

Pinelli E., Kellick-Kendrick R., Wagenaar J., Bernadina W., Real G. \& Ruitenberg J. 1994. Cellular and humoral immune responses in dogs experimentally and naturally infected with Leishmania infantum. Infect. Immun. 62:229-235.

Pinelli E., Gonzalo R.M., Boog C.J.P., Rutten V.P.M.G., Gebhard D., Real G. \& Ruitenberg E.J. 1995. Leishmania infantum-specific T cell lines derived from asymptomatic dogs that lyse infected macrophages in a major histocompatibility complex-restricted manner. Europ. J. Immunol. 25:1594-1600.

Reis A.B., Teixeira-Carvalho A., Giunchetti R.C., Guerra L.L., CarvaIho M.G., Mayrink W., Genaro O., Corrêa-Oliveira R. \& Martins-Filho O.A. 2006a. Phenotypic features of circulating leucocytes as immunological markers for clinical status and bone marrow parasite density in dogs naturally infected by Leishmania chagasi. Clin. Exp. Immunol. 146:303-311.

Reis A.B., Martins-Filho O.A., Teixeira-Carvalho A., Carvalho M.G., Mayrink W., França-Silva J.C., Giunchetti R.C., Genaro O. \& CorrêaOliveira R. 2006b. Parasite density and impaired biochemical/ hematological status associated with severe clinical aspects of canine visceral leishmaniasis. Res. Vet. Sci. 81:68-75.

Sacks D.L., Lal S.L., Shrivastava S.N., Blackwell J. \& Neva F.A. 1987. An analysis of $T$ cell responsiveness in Indian kala-azar. J. Immunol. 138:908-913.

Slappendel R.J. 1988. Canine leishmaniasis: A review based on 95 cases in the Netherlands. Vet. Quart. 10:1-16.

Souza S.L.P., Guimarães-Junior J.S., Ferreira F., Dubey J.P. \& Gennari S.M. 2002. Prevalence of Neospora caninum antibodies in dogs from dairy farms in Paraná, Braz. J. Parasitol. 88:408409.

Souza S.L.P., Gennari S.M., Yai L.E.O., D’Áuria S.R.N.D., Cardoso S.M.S., Guimarães-Junior J.S. \& Dubey J.P. 2003. Occurrence of Toxoplasma gondii antibodies in sera from dogs of the urban and rural areas from Brazil. Braz. J. Vet. Parasitol. 12:1-3.

Tarantino C., Rossi G., Kramer L.H., Perrucci S., Cringoli G. \& MacChioni G. 2001. Leishmania infantum and Neospora caninum simultaneous skin infection in a young dog in Italy. Vet. Parasitol. 102:77-83.

Voller A., Bidwell D.E. \& Barlett A. 1979. The enzyme linked immunossorbente assay (ELISA): A guide with abstracts of microplate applications, Guernsey: Dynatech. London. 124p.

Wanha K., Edelhofer R., Gabler-Eduardo C. \& Prosl H. 2005. Prevalence of antibodies against Neospora caninum and Toxoplasma gondii in dogs and foxes in Austria. Vet. Parasitol. 128:189-193.

WHO 1997. The current global situation of HIV/AIDS pandemic. Weekly Epidemiol. Rec. 72:357-360.

Wolday D., Berhe N., Akuffo H. \& Britton S. 1999. Leishmania-HIV interaction: Immunopathogenic mechanisms. Parasitol. Today 15: 182-187.

Wouda W., Dijkstra T., Kramer A.M.H., Van Maanen C. \& Brinkhof J.M.A. 1999. Seroepidemiological evidence for a relationship between Neospora caninum infections in dogs and cattle. Int. J. Parasitol. 29:1677-1682. 